\title{
Struktur Hepar dan Rasio Bobot Hepar Terhadap Bobot Tubuh Mencit (Mus Musculus L.) Jantan Setelah Pemberian Ekstrak Etanol Daun Mimba (Azadirachta Indica A.Juss)
}

\section{Liver Structure and Ratio of Liver Weight to The Body Weight of Male Mice (Mus musculus L.) After Giving Ethanol Extract of NeemLeaves(Azadirachta indica A.Juss)}

\author{
Ratih Nur Fitriani $^{1 *}$, Agung Janika Sitasiwi ${ }^{2}$, Sri Isdadiyanto ${ }^{2}$ \\ ${ }^{1}$ Program Studi Biologi, Fakultas Sains dan Matematika, Universitas Diponegoro \\ ${ }^{2}$ Departemen Biologi, Fakultas Sains dan Matematika, Universitas Diponegoro \\ *Email : fitrianiratih08@gmail.com
}

Diterima 27 Juni 2019 / Disetujui 5 Februari 2020

\begin{abstract}
ABSTRAK
Penelitian ini bertujuan untuk mengetahui struktur hepar dan rasio bobot hepar terhadap bobot tubuh mencit (Mus musculus L) jantan setelah pemberian ekstrak etanol daun mimba (Azadirachta indica A.Juss). Penelitian ini menggunakan 2 kelompok perlakuan yaitu Kontrol (akuades) dan Perlakuan (mimba). Perlakuan diberikan secara oral selama 21 hari. Hepar ditimbang dan dibuat preparat menggunakan metode parafin dengan pewarnaan Hematoksilin Eosin. Pengukuran diameter hepatosit dilakukan dalam 4 bidang pandang. Bobot hepar dan bobot tubuh digunakan untuk menghitung nilai HSI. Data dianalisis dengan uji t. Hasil analisis menunjukan adanya pengaruh nyata terhadap diameter hepatosit tetapi menunjukan pengaruh tidak nyata terhadap bobot tubuh, bobot hepar dan nilai Hepatosomatik indek (HSI). Hal ini dapat disimpulkan bahwa pemberian ekstrak etanol daun mimba (Azadirachta indica) sebagai obat tradisional dengan dosis $14 \mathrm{mg} / \mathrm{KgBB}$ tidak mempengaruhi struktur hepar dan rasio bobot hepar terhadap bobot tubuh mencit (Mus musculus) jantan.
\end{abstract}

Kata kunci : daun mimba, hepar, diameter hepatosit dan HSI

\section{ABSTRACT}

The aim of this study was to determine the liver structure and the ratio of liver weight to the body weight of male mice (Mus musculus L) after the administration of ethanolic of neem leaves (Azadirachta indica A.Juss) extract. This study using 2 treated groups, namely control (aquadest) and treated group (neem). Treatment was given orally 21 days. The liver weighed and contiuned by histologically prepared with paraffin method, using HE staining. Measurement of hepatocyte diameter were carried out in every 4 fields of the organs. The liver weight and body weight were used to calculate HSI value. Data was analyzed by t test. The results showed a significant effect on the hepatocyte diameter but showed no significant effect on body weight, liver weight and Hepatosomatic index value (HSI). It could be concluded that treated with the ethanolic neem leaves extract during 22 days was safe to the male mice liver structure. It can be concluded that the administration of ethanolic of neem leaves (Azadirachta indica A.Juss) extract as traditional medicine with dose of $14 \mathrm{mg} / \mathrm{KgBW}$ did not effect the liver structure and the ratio of liver weight to the body weight of male mice (Mus musculus $\mathrm{L}$ ).

Keywords : neem leaves, liver, hepatocyte diameter and HIS

\section{PENDAHULUAN}

Mimba merupakan tanaman yang banyak ditemukan di Indonesia. Tanaman mimba di Bali jumlahnya diperkirakan kurang lebih 500.000 pohon (Odoh dan Bratte 2015). Daun mimba (Azadirachta indica A. Juss) memiliki efek antiinflamasi, antibakterial, antifungal dan antioksidan. Daunnya mengandung beberapa komponen hasil produksi metabolit sekunder seperti flavonoid, saponin, tanin, azadirachtin, salanin, meliantriol, nimbin dan nimbidin yang diduga sangat bermanfaat, baik dalam bidang pertanian (pestisida dan pupuk), maupun farmasi (kosmetik dan obat-obatan) (Pandey et al., 2014). Beberapa senyawa yang bersifat toksik adalah 
azadirachtin, nimbin, nimbidin, dan salannin (Suryawanshi, 2011). Hepar merupakan salah satu organ dalam tubuh yang berfungsi sebagai alat detoksifikasi sehingga hepar sangat rentan terhadap zat-zat yang bersifat toksik. Kupradinun et al. (2012) menyatakan bahwa efek samping nimba diduga dapat menyebabkan kerusakan struktur hati dan ginjal. Sitasiwi et al. (2018) telah membuktikan bahwa ekstrak ethanol daun Mimba menyebabkan peningkatan bobot hepar. Ghimeray et al. (2009) menyatakan bahwa ekstrak daun mimba pada 200 $\mathrm{g} / \mathrm{kg}$ berat badan dapat menyebabkan pengurangan berat badan hewan disertai dengan gejala seperti kelemahan, anoreksia dan cacat histopatologis. Omotayo et al. (2012) telah membuktikan bahwa ekstrak etanol kulit kayu tanaman mimba menyebabkan meningkatnya rasio berat tubuh dan berat hepar tikus.

Berdasarkan latar belakang tersebut maka dilakukan penelitian ini. Tujuan dari penelitian ini adalah untuk mengetahui struktur histologi hepar dan rasio bobot hepar terhadap bobot tubuh mencit (Mus musculus L) jantan setelah pemberian ekstrak etanol daun mimba (Azadirachta indica A.Juss). Penelitian ini juga dilakukan pengukuran terhadap diameter hepatosit mencit jantan untuk mengetahui apakah terjadi pembengkakan pada sel hepar. Pembengkakan sel merupakan salah satu indikasi adanya kerusakan yang bersifat reversibel. Selain itu juga dilakukan pengamatan terhadap struktur morfologi hepar.

\section{METODE PENELITIAN}

Alat yang digunakan dalam penelitian ini yaitu 10 set kandang mencit, botol minum mencit, neraca Ohaus, Hygrometer, kompor listrik, erlenmeyer, gelas beaker, jarum gavage, box plastik bertutup, 1 set alat bedah, timbangan analitik, seperangkat alat pembuatan preparat awetan (mikrotom rotary, pisau mikrotom rotary, gelas benda, gelas penutup), dan fotomikrograf. Bahan yang digunakan dalam penelitian ini yaitu 30 ekor mencit jantan, ektrak etanol daun mimba yang berbentuk serbuk, air, pakan ayam komersial (hiprovite 594), larutan BNF 10\%, larutan Nacl 0,95\%, kloroform dan seperangkat bahan pembuatan preparat (larutan BNF 10\%, alkohol, toluol, xylol, parafin, canada balsem dan perwarna hematoksilin dan eosin). Penelitian ini menggunakan desain Rancangan Acak Lengkap (RAL) dengan 2 kelompok perlakuan yaitu kelompok kontrol (akuades) dan kelompok perlakuan (mimba). Sebelum dilakukan perlakuan, mencit di aklimasi terlebih dahulu selama 12 hari untuk penyesuaian hewan uji dengan lingkungan penelitian dan perlakuan oleh peneliti. Pembuatan larutan ekstrak etanol daun mimba yaitu dengan melarutkan serbuk kering daun mimba sebanyak 1,68 gram dengan aquades bersuhu $80^{\circ} \mathrm{C}$ sebanyak 39,8 ml. Larutan mimba dan kontrol diberikan sebanyak $0,2 \mathrm{ml}$ pada setiap mencit selama 21 hari. Perlakuan kontrol dan mimba dilakukan secara oral menggunakan jarum gavage dengan frekuensi sehari satu kali.

Bobot tubuh mencit ditimbang setiap 7 hari sekali untuk mengetahui perubahan bobot mencit. Isolasi sampel dilakukan setelah 21 hari perlakuan yaitu pada hari ke 22, sebelum dilakukan pembedahan bobot tubuh mencit ditimbang terlebih dahulu menggunakan neraca Ohaus. Mencit dibius menggunakan kloroform lalu dibedah dengan menyayat bagian abdominal bawah sampai thoracal. Organ hepar diambil dan ditimbang terlebih dahulu sebelum diisolasi kedalam tabung sampel yang berisi larutan fiksatif BNF $10 \%$. Pembuatan preparat histologi sel hepar dilakukan dengan metode parafin dan pewarnaan Hematoksilin Eosin (HE). Pengamatan struktur histologi dan pengukuran diameter hepatosit dilakukan dibawah fotomikograf dengan perbesaran 200x dan 400x. Rasio bobot hepar terhadap bobot tubuh mencit dilakukan dengan membagi bobot hepar dengan bobot tubuh kemudian dikalikan 100. Wahyuningtyas dkk. (2018) menyatakan bahwa pengukuran diameter hepatosit dilakukan di bawah fotomikrograf dengan perbesaran 400x dengan cara membagi penampang menjadi tegak lurus berdasarkan garis horizontal (x) dan garis vertikal (y) apabila penampang hepatosit berbentuk bulat. Penampang hepatosit berbentuk oval maka pengukuran diameter hepatosit dengan cara membagi penampang hepatosit secara tegak lurus berdasarkan jarak terdekat (y) dan jarak terjauh $(\mathrm{x})$. Data yang diperoleh dari penelitian ini 
dianalisis menggunakan uji t dengan program SPSS versi 17 dengan taraf kepercayaan 95\%.

\section{HASIL DAN PEMBAHASAN}

Hasil penelitian mengenai bobot tubuh, bobot hepar, nilai HSI dan diameter hepatosit mencit (Mus musculus) jantan setelah pemberian ekstrak etanol daun mimba disajikan dalam Tabel 1. Berdasarkan uji t pada Tabel (1) pemberian ekstrak etanol daun mimba memberikan pengaruh nyata $(\mathrm{p}<0,05)$ terhadap diameter hepatosit mencit (Mus musculus) jantan, tetapi memberikan pengaruh tidak nyata terhadap bobot tubuh, bobot hepar dan nilai HSI (Hepatosomatic index). Pemberian larutan ekstrak etanol daun mimba dengan dosis $14 \mathrm{mg} / \mathrm{KgBB}$ yang diberikan selama 21 hari tidak mempengaruhi bobot tubuh mencit jantan. Hasil penelitian ini dapat diartikan bahwa pemberian ekstrak etanol daun mimba tidak menyebabkan pertambahan maupun penurunan bobot tubuh yang signifikan. Rerata bobot tubuh mencit kelompok kontrol dan kelompok perlakuan tidak jauh berbeda yaitu 35,79 gram dan 36,63 gram. Penelitian yang dilakukan oleh Ashafa et al. (2012) menjelaskan bahwa pemberian ekstrak etanol kulit batang mimba pada dosis $50-100 \mathrm{mg} / \mathrm{kgBB}$ belum dapat memengaruhi bobot tubuh tikus jantan bila dibandingkan kelompok kontrol. Hasil penelitian Hasana dkk. (2019) juga menjelaskan bahwa pemberian ekstrak etanol daun mimba pada semua perlakuan dengan dosis $8,4 \mathrm{mg} / \mathrm{kgBB}, \quad 11,2$ $\mathrm{mg} / \mathrm{kgBB}$ dan $14 \mathrm{mg} / \mathrm{kgBB}$ tidak mempengaruhi bobot tubuh mencit betina. Hasil penelitian tersebut sama dengan penelitian ini sehingga dapat diduga bahwa efek pemberian ekstrak etanol daun mimba tidak terpengaruh oleh jenis kelamin.

Tabel 1. Rerata bobot, tubuh, bobot hepar, nilai HSI dan diameter hepatosit mencit jantan setelah pemberian ekstrak etanol daun mimba.

\begin{tabular}{lcc}
\hline & & Perlakuan \\
Variabel & $\mathrm{K}$ & $\mathrm{P}$ \\
& $\bar{X} \pm S D$ & $\bar{X} \pm S D$ \\
\hline Bobot Tubuh $($ gram $)$ & $35,79^{\mathrm{a}} \pm 3,28$ & $36,63^{\mathrm{a}} \pm 3,47$ \\
Bobot Hepar $(\mu \mathrm{m})$ & $1,75^{\mathrm{a}} \pm 0,25$ & $1,85^{\mathrm{a}} \pm 0,22$ \\
Nilai HSI $(\%)$ & $4,85^{\mathrm{a}} \pm 0,49$ & $5,06^{\mathrm{a}} \pm 0,37$ \\
Diameter Hepatosit $(\mu \mathrm{m})$ & $27,05^{\mathrm{a}} \pm 2,45$ & $33,71^{\mathrm{b}} \pm 5,05$ \\
\hline
\end{tabular}

Keterangan: Data disajikan berupa rataan $(\bar{X}) \pm$ standar deviasi (SD). Rerata yang diikuti superskrip yang sama pada baris yang sama menunjukan pengaruh tidak nyata $(\mathrm{p}<0,05)$ dengan uji $\mathrm{t}$ pada taraf kepercayaan 95\%. K : kelompok kontrol, P: kelompok perlakuan.

Hasil uji $\mathrm{t}$ terhadap bobot hepar menunjukkan pengaruh tidak nyata $(p>0,05)$. Rerata bobot hepar pada kelompok kontrol yaitu 1,75 gram sedangkan pada kelompok perlakuan yaitu 1,85 gram. Rogers dan Renee (2012) menyatakan bahwa berat hepar mencit berkisar antara 1,5-2 gram. Hal ini menunjukkan bahwa bobot hepar mencit pada penelitian ini masih tergolong normal. Hasana dkk. (2019) menyatakan bahwa paparan ekstrak etanol daun mimba terhadap bobot hepar mencit betina menunjukkan hasil yang berbeda tidak bermakna. Harbison et al. (2015) menyatakan hepar merupakan organ target toksisitas, paparan zat toksik dalam tubuh dapat menaikkan ataupun menurunkan bobot hepar. Penelitian ini tidak terjadi kenaikan maupun penurunan bobot hepar, hal tersebut diduga karena kandungan senyawa dalam ekstrak etanol daun mimba dapat dimetabolisme dan didetoksifikasi dalam organ hepar.

Nilai HSI merupakan rasio bobot hepar terhadap bobot tubuh mencit. Hasil uji statistik nilai HSI dari penelitian ini menunjukkan pengaruh tidak nyata $(p>0,05)$. Nilai HSI kelompok kontrol yaitu $4,85 \%$ sedangkan untuk kelompok perlakuan yaitu 5,06\%. Hasana dkk. (2019) menyatakan bahwa paparan ekstrak etanol daun mimba hingga dosis $14 \mathrm{mg} / \mathrm{kg}$ BB selama 21 hari menunjukkan 
hasil berbeda tidak bermakna terhadap nilai HSI mencit betina. Hasil penelitian tersebut sama dengan penelitian ini sehingga dapat diduga bahwa efek paparan ekstrak etanol daun mimba terhadap nilai HSI juga tidak bergantung pada jenis kelamin.

Hasil uji $t$ terhadap diameter hepatosit menunjukkan adanya pengaruh nyata $(\mathrm{p}<0,05)$. Data hasil pengamatan juga menunjukkan diameter hepatosit yang diberi paparan ekstrak etanol daun mimba memiliki ukuran yang lebih besar daripada kontrol yaitu berkisar 27,05 $\mu \mathrm{m}$ dan 33,71 $\mu \mathrm{m}$ untuk kelompok perlakuan. Ukuran diameter hepatosit pada kelompok perlakuan lebih besar daripada kelompok kontrol diduga merupakan suatu indikasi pembengkakan sel. Hasil penelitian Hasana dkk. (2019) diameter hepatosit normal mencit betina baik kontrol maupun perlakuan mimba berkisar antara 10-20 $\mu \mathrm{m}$. Penelitian ini tidak ada penurunan atau kenaikan bobot tubuh maupun bobot organ hepar. Hal ini sama dengan penelitian yang dilakukan oleh Wahyuningtyas dkk.
(2018) bahwa peningkatan diameter hepatosit diduga bukan merupakan suatu tanda kerusakan permanen hepatosit. Adanya kerusakan permanen hepatosit seharusnya diikuti oleh penurunan atau kenaikan bobot tubuh dan bobot organ yang signifikan terhadap suatu individu.

Pengamatan morfologi yang dilakukan pada organ hepar kelompok kontrol dan perlakuan menunjukan tidak ada perbedaan. Hepar kelompok kontrol dan perlakuan sama-sama memiliki warna merah kecoklatan yang dapat dilihat pada Gambar 1. Pengamatan struktur histologi sel hepar yang dilakukan dibawah mikroskop menunjukkan adanya perbedaan ukuran sel hepatosit antara kelompok kontrol dan kelompok perlakuan. Sel hepatosit pada kelompok perlakuan memiliki ukuran yang lebih besar daripada kelompok kontrol. Inti sel dan sitoplasma terlihat lebih menggembung daripada kelompok kontrol, sitoplasma juga tampak lebih lebar.

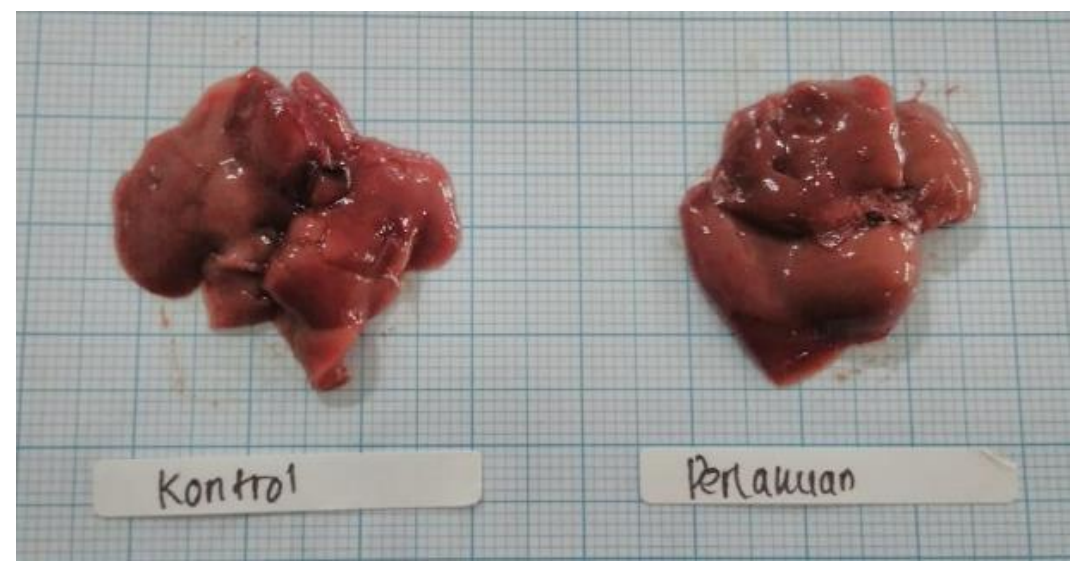

Gambar 1. Morfologi Hepar Mencit Kelompok Kontrol dan Perlakuan.

Dewi dan Saraswati (2009) menyatakan bahwa gangguan pengaturan cairan dalam sel mengakibatkan adanya influks air ke dalam sel, akibatnya sebagian organela seperti retikulum endoplasma, mitokondria berubah menjadi kantong-kantong yang berisi air, sehingga pada pengamatan dibawah mikroskop terlihat sel membesar dengan gambaran vakuola pada sitoplasma sel. Mekanisme terjadinya pembengkakan sel yaitu dalam cairan tubuh terdapat berbagai macam elektrolit, baik yang berada di luar sel maupun berada di dalam sel.
Keseimbangan ion $\mathrm{Na}+$ dan $\mathrm{K}+$ di dalam dan diluar sel harus terjaga untuk menjaga kestabilan lingkungan internal sel. Sel harus mengeluarkan energi metabolik untuk memompa ion $\mathrm{Na}+$ keluar dari sel. Jika terjadi kerusakan sel, maka sel tidak mampu memompa ion $\mathrm{Na}+$ keluar dari sel, akibatnya yaitu terjadinya influks air kedalam sel karena terjadi osmosis yang berakibat pada perubahan struktur sel yang berupa pembengkakan sel. Hal ini yang menyebabkan sel hepatosit pada kelompok perlakuan memiliki inti sel lebih besar dan sitoplasma juga terlihat lebih 
lebar daripada kelompok kontrol. Hasil pengamatan struktur mikroskopis sel hepar dapat dilihat pada Gambar 2.

Maulida dkk. (2013) menyatakan bahwa perubahan struktur sel hepar dapat bersifat reversibel dan irreversibel. Dewi dan Saraswati (2009) menyatakan bahwa perubahan struktur sel yang berupa pembengkakan sel disebut sebagai perubahan degeneratif. Perubahan struktur sel degeneratif merupakan perubahan yang bersifat reversibel dimana sel dapat kembali ke struktur normal. Mekanisme tersebut diduga terjadi pada penelitian ini sehingga bobot hepar dan nilai HSI setelah diuji statistik menujukkan hasil tidak berbeda nyata, selain itu pengamatan secara mikroskopis ditemukan adanya kerusakan sel hepar seperti degenerasi parenkimatosa dan degenerasi hidropik yang dapat dilihat pada Gambar 2.
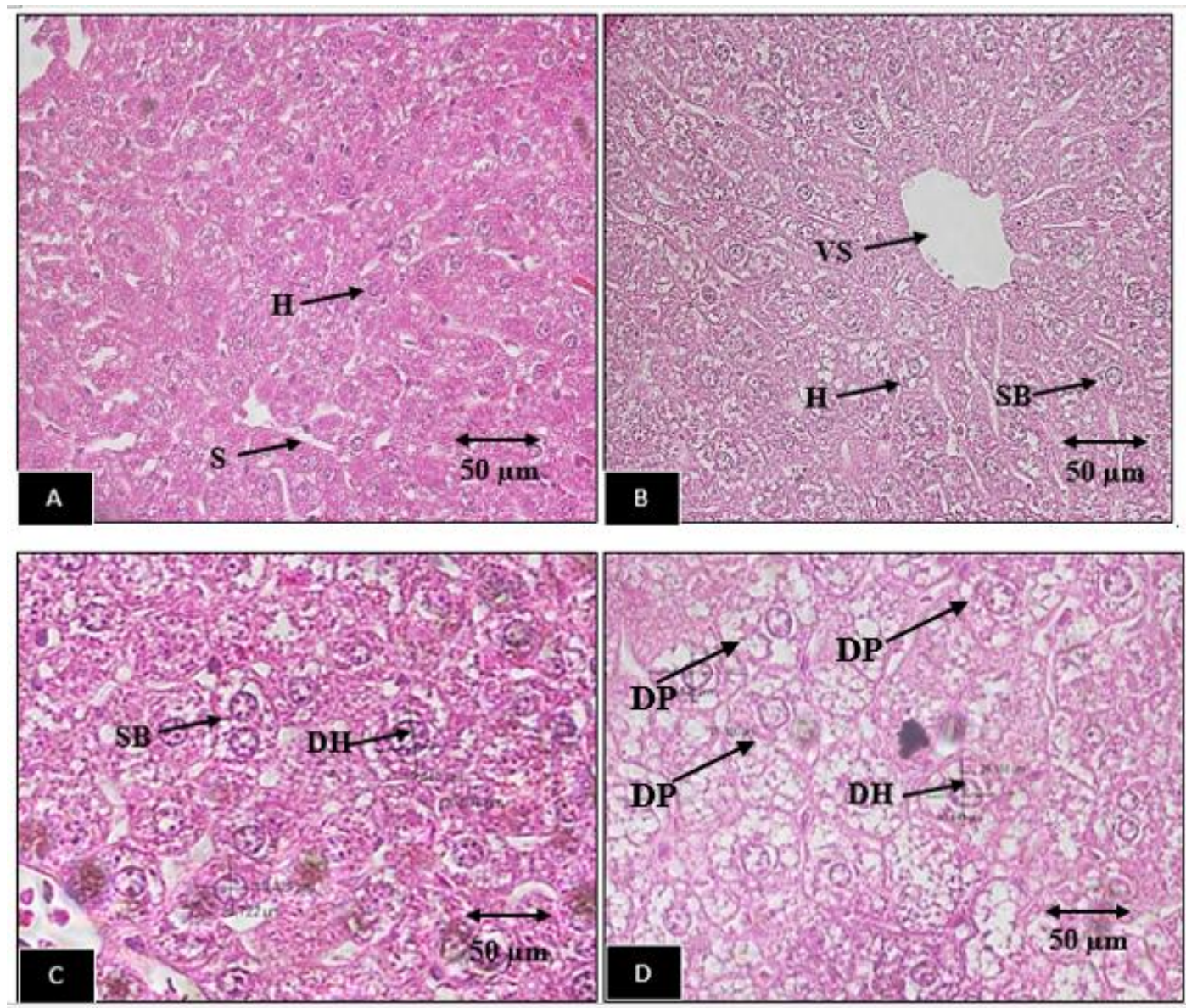

Gambar 2. Struktur mikroskopis sel hepar mencit (Mus musculus) jantan. Pewarnaan HE dengan perbesaran 200x (A\&B) dan 400x (C\&D). Keterangan : (A) dan (C) kelompok kontrol, (B) dan (D) kelompok perlakuan, (H) hepatosit, (S) sinusoid, (VS) vena sentralis, dan (DH) diameter hepatosit.

Wahyuningtyas dkk. (2018) menyatakan bahwa kerusakan hepatosit ditandai dengan adanya degenerasi sel. Tamad dkk. (2011) menyatakan bahwa degenerasi merupakan cedera karena toksik dan dapat menyebabkan pembengkakan atau edema hepatosit. Degenerasi sel dapat berupa degenerasi parenkimatosa, hidropik dan melemak. Utomo dkk. menyatakan bahwa degenerasi parenkimatosa merupakan degenerasi paling ringan yang ditandai dengan adanya pembengkakan dan kekeruhan sitoplasma. Degenerasi ini bersifat reversibel karena hanya terjadi pada mitokondria dan retikulum endoplasma akibat gangguan oksidasi. Sel tidak dapat mengeliminasi air sehingga tertimbun di dalam sel dan sel 
mengalami pembengkakan. Degenerasi hidropik merupakan derajat kerusakan yang lebih berat, tampak vakuola yang terisi air dalam sitoplasma yang tidak mengandung lemak atau glikogen. Degenerasi tersebut bersifat reversibel meskipun tidak menutup kemungkinan bisa menjadi irreversibel apabila penyebab cederanya menetap.Wahyuningtyas dkk. (2018) menyatakan bahwa akumulasi cairan di dalam sel karena degenerasi hidropik disebabkan oleh adanya akumulasi cairan akibat kegagalan sel dalam mempertahankan homeostasis, dalam penelitian ini degenerasi tersebut tidak ditemukan.

Maulida dkk. (2013) menyatakan bahwa degenerasi yang berlangsung secara terus menerus akan menyebabkan kerusakan sel yang ditandai dengan kematian sel secara permanen yang disebut nekrosis. Andreas dkk. (2015) menyatakan bahwa hepatosit yang mengalami degenerasi lemak tampak sebagai sel yang memiliki vakuola kecil (mikrovesikular) disitoplasma pada tahap awal sel.

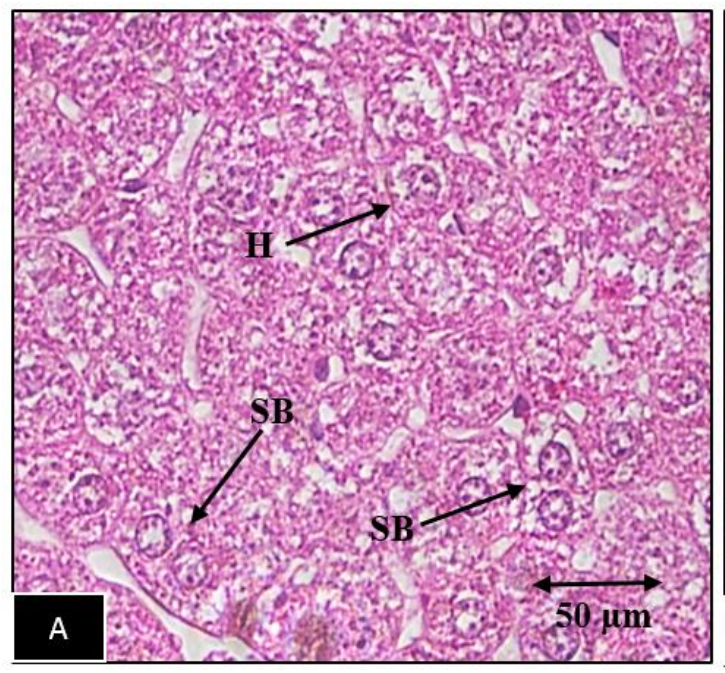

dan akan berkembang menjadi vakuola yang berukuran lebih besar (makrovesikular) sehingga menekan nukleus ke tepi. Amalia (2009) menyatakan bahwa nekrosis adalah kematian sel atau jaringan pada makluk hidup terlihat pada perubahan mikroanatominya. Inti sel menjadi lebih padat (piknotik) dan dapat hancur bersegmensegmen (karioreksis) kemudian sel menjadi esinofilik. Penelitian ini tidak ditemukan adanya kerusakan yang berupa nekrosis.

Mimba (Azadirachta indica A Juss) merupakan bahan alam yang kaya manfaat. Daun mimba memiliki kandungan senyawa azadirichtin, flavonoid, tritepenoid dan saponin (Auta dan Hasan, 2016). Senyawa aktif dari daun mimba adalah flavonoid, fenolik, triterpenoid, dan tannin (Whary, 2015). Inaya et al. (2015) menambahkan bahwa senyawa flavonoid dapat mendenaturasi protein pada membran sel, sehingga membran sel tersebut terganggu permeabilitasnya dan menyebabkan kebocoran

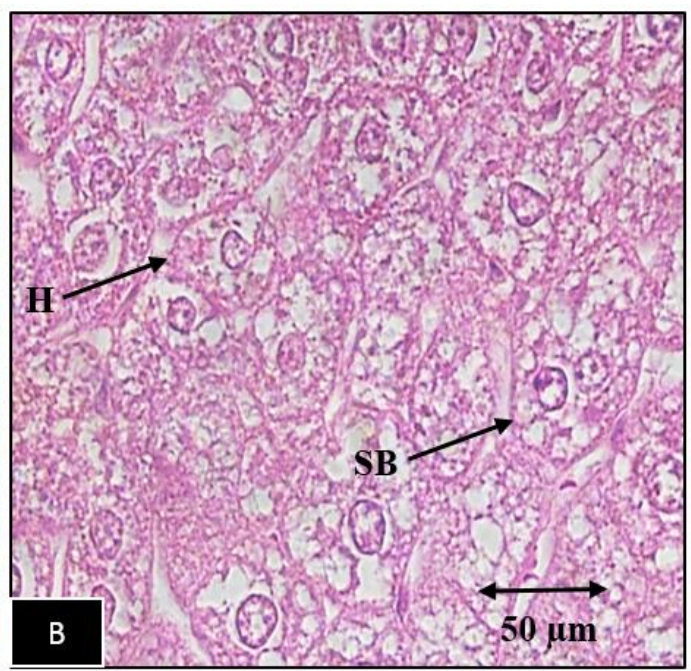

Gambar 3. Struktur mikroskopis sel binukleat hepar mencit (Mus musculus) jantan. Pewarnaan HE dengan perbesaran 400x. Keterangan : (A) kontrol,(B) perlakuan, (H) hepatosit, (IS) inti sel, (S) sinusoid dan (SB) sel binukleat

Senyawa aktif yang terisolasi dalam ekstrak etanol daun mimba antara lain karbohidrat, glikosida, protein, senyawa fenol, tanin, flavonoid dan saponin (Singh and Chauhan, 2014). Senyawa nimbidin daun mimba berperan sebagai agen hipoglikemik (Pankaj et $a l ., 2011)$, diduga dapat menurunkan ketersediaan energi dalam tubuh hewan uji yang dapat berpengaruh pada nilai HSI. Tanin merupakan metabolit sekunder yang memiliki efek anti mitotik dan bersifat sitotoksik pada sel yang mengalami pembelahan cepat (Setyowati et al., 2015). Hasana dkk. (2019) menyatakan bahwa kandungan senyawa tanin pada daun mimba dengan dosis 
$14 \mathrm{mg} / \mathrm{kg}$ BB diduga belum dapat mempengaruhi proses regenerasi sel sehingga tidak mempengaruhi bobot badan, bobot hepar dan nilai HSI.

Jika hepar terus menerus terpapar obat dan zat kimia dalam jangka panjang maka sel-sel pada hepar dapat mengalami perubahan terutama pada sel hepatosit seperti degenerasi lemak dan nekrosis yang dapat menurunkan kemampuan regenerasi sel sehingga menyebabkan kerusakan permanen sampai kematian sel (Anggraeny et al., 2014). Hal tersebut tidak ditemukan pada penelitian ini. Menurut Pramesti dkk (2017) sel-sel hepar dapat memperbaiki dirinya secara fisiologis dan menggantikannya dengan sel baru ketika terjadi suatu kerusakan yang sifatnya reversibel, dalam penelitian ini kemungkinan terjadi proses regenerasi sel hati dengan baik yang dibuktikan dengan banyak ditemukannya sel binukleat yang dapat dilihat pada Gambar 3.

Berdasarkan hasil penelitian yang didapatkan, diameter hepatosit pada kelompok perlakuan yang diberi ekstrak etanol daun mimba dengan dosis $14 \mathrm{mg} / \mathrm{KgBB}$ selama 21 hari memiliki ukuran lebih besar dari kelompok kontrol. Hal ini dapat diartikan bahwa terdapat pengaruh yang signifikan tetapi masih aman. Hasil uji statistik pada bobot tubuh, bobot hepar dan nilai HSI juga menunjukkan pengaruh tidak nyata, selain itu pengamatan yang dilakukan secara mikroskopis juga tidak ditemukan adanya kerusakan sel seperti degenerasi hidropik, degenerasi melemak dan nekrosis. Hal tersebut diduga adanya daya regenerasi hepar yang dibuktikan dengan banyak ditemukannya sel binukleat.

\section{KESIMPULAN}

Hasil dari penelitian ini dapat disimpulkan bahwa pemberian ekstrak etanol daun mimba (Azadirachta indica) sebagai obat tradisional dengan dosis $14 \mathrm{mg} / \mathrm{KgBB}$ tidak mempengaruhi struktur hepar dan rasio bobot hepar terhadap bobot tubuh mencit (Mus musculus) jantan.

\section{UCAPAN TERIMAKASIH}

Penelitian ini didanai oleh Fakultas Sains dan Matematika Universitas Diponegoro melalui No.1754I/UN7.5.8/PG/2018 Sumber dana selain APBN Fakultas Sains dan Matematika UNDIP tahun 2018.

\section{DAFTAR PUSTAKA}

Amalia, N. 2009. Uji Toksisitas Akut Ekstrak Valerian (Valeriana officinalis) terhadap Hepar Mencit BALB/C. Karya Tulis Ilmiah. Semarang: Fakultas Kedokteran, Universitas Diponegoro Semarang.

Andreas, H., H.F. Trianto, M.I. Ilmiawan. 2015. Gambaran Histologis Regenerasi Hati Pasca Penghentian Pajanan Monosodium Glutamat pada Tikus Wistar. Jurnal Fakultas Kedokteran Universitas Tanjungpura, 3(1):29-36.

Anggraeny, E., Tjdanrakirana dan Nur Ducha. 2014. Pengaruh Pemberian Filtrat Tauge Kacang Hijau terhadap Histologi Hepar Mencit Yang Terpapar MSG. Jurnal Lenterabio, 3(3): 186-191.

Ashafa AOT, LO Orekoya, and MT Yakubu. 2012. Toxicity profile of ethanolic extract of Azadirachta indica Stem Bark in male wistar rats. Asian Pacific Journal of Tropical Biomedicine, 2(10): 811-817.

Auta, T. and A. T. Hassan. 2016. Reproductive toxicity of aqueous wood-ash extract of Azadirachta indica (neem) on male albino mice. Annals of Biological Researc, 1(2) : 108-113.

Dewi, U.K., dan T.R. Saraswati. 2009. Efek rebusan daun tapak dara pada dosis dan frekuensi yang berbeda terhadap kerusakan dan akumulasi glikogen pada hepar mencit (Mus musculus). Jurnal Bioma, 1(11):1-5.

Ghimeray, A. K., C. W. Jin, B. K. Ghimire, and D. H. Cho. 2009. Antioxidant activity and quantitative estimation of azadirachtin and nimbin in Azadirachta Indica A. Juss grown in foothills of Nepal. African Journal of Biotechnology, 8 (13). 
Harbison, RD, MM Bourgeois, and GT Johnson. 2015. Hamilton \& Hardy's Industrial Toxicology. New Jersey: John Wiley \& Sons Inc.

Hasana, A.N., A.J. Sitasiwi dan S. Isdadiyanto. 2019. Hepatosomatik Indeks Dan Diameter Hepatosit Mencit (Mus musculus L.) Betina Setelah Paparan Ekstrak Etanol Daun Mimba (Azadirachta indica Juss.). Jurnal Pro-life. 1(6).

Inaya, A. F. N., Kismiyati, dan S. Subekti. 2015. Pengaruh perasan biji pepaya (Carica papaya) terhadap kerusakan telur Argulus japonicus. Jurnal Ilmiah Perikanan dan Kelautan, 7(2): 159-164.

Kupradinun, P., A. Tepsuwan, N. Tanthasri, N. Meesiripan, S. Tunsakul, W. Tompat, Y. Jarratwisautpom, and W. R. Kusamran. 2012. Toxicity Testing of Flowers of Neem Tree (Azadirachta indica A. Juss). Thai J. Vet. Med, 40(1): 47-55.

Maulida, A., S. Ilyas dan S. Hutahean. 2013. Pengaruh Pemberian Vitamin $\mathrm{C}$ dan E Terhadap Gambaran Histologi Hepar Mencit (Mus musculus L.) yang Dipajankan Monosodium Glutamat (MSG). Saintia Biologi, 1(2):15-20.

Odoh, L. I., and L. Bratte. 2015. Effects of varying levels of neem (Azadirachta indica) leaf meal in layer diets on the haematological and serological indices, and faecal bacterial counts of layers. J Nat Sci Res, 5(4): 37-44.

Omotayo, A., T. Ashafa, L. O. Orekayo, M.T. Yakubu. 2012. Toxicity profile of ethanolic extract of Azadirachta indica stem bark in male Wistar rats. Asian Pac Journal Trop Biomed, 2(10): 811-817.

Pandey, G., M. M. Verma and M. Singh. 2014. Evaluation of phytochemical, antibacterial and free radical scavenging properties of Azadirachta indica (neem) leaves. Int $J$ Pharm Pharm Sci, 6 (2) : 444-447.

Pankaj, S., T. Lokeswar, B. Mukesh, and B. Vishnu, 2011. Review on Neem (Azadirachta indica): A thousand problem one solution. International Research Journal of Pharmacy, 2(12): 97-102.
Pramesti, N. K. T., N. I. Wiratmini, dan N. P. A. Astiti. 2017. Struktur Histologi Hati Mencit (Mus musculus L.) Setelah Pemberian Ekstrak Daun Ekor Naga (Rhapidhophora pinnata Schott). Jurnal Simbiosis, (2): 4346.

Rogers, A.B., and Z.D. Renee. 2012. Comparative Anatomy and Histology: A Mouse and Human Atlas. USA: Elsevier Inc.Hlm. 193196.

Setyowati, W. A. E., S. R. D., Ariani, Ashadi, B Mulyani, dan A Hidayat. 2015. Aktivitas antifertilitas kontrasepsi dari kulit durian (Durio zibethinus Murr) varietas Petruk. Seminar Nasional Kimia dan Pendidikan Kimia VII. Program Studi Pendidikan Kimia Jurusan FMIPA FKIP UNS, Surakarta.

Singh, V and D. Chauhan. 2014. Phytochemical evaluation of aqueous and ethanolic extract of neem leaves (Azadirachta indica). Indo American Journal of Pharmaceutical Research, 14(12): 59435948.

Sitasiwi, A. J. and S. M. Mardiati. 2018. Effect of ethanolic Neem (Azadirachta indica) leaf extract as an herb contraceptive on Hepatosomatic Index of the male mice (Mus musculus). Department of Biology, Faculty of Sciences and Mathematics, Diponegoro University, Semarang.

Suryawanshi, J. A. S., 2011. Neem-natural contraceptive for male and female-an overview. IJBB. 11(2):1-6.

Tamad, F.S.U., Z.S. Hidayat, dan H. Sulistiyo. 2011. Gambaran Histopatologi Hepatosit Tikus Putih Setelah Pemberian Jintan Hitam Dosis $500 \mathrm{mg} / \mathrm{Kgbb}$, $1000 \mathrm{mg} / \mathrm{Kgbb}$, dan $1500 \mathrm{mg} / \mathrm{Kgbb}$ Selama 21 Hari(Subkronik). Mandala of Health, $5(3): 1-5$.

Utomo, Y., A. Hidayat,, M. Dafib, dan F.A. Sasi. 2012. Studi Histopatologi Hati Mencit (Mus musculus L.) yang Diinduksi Pemanis Buatan. Jurnal MIPA UNNES, 35(2):122-129. 
Wahyuningtyas, P., A. J. Sitasiwi, dan S. M. Mardiati. 2018. Hepatosomatic Index (HSI) Dan Diameter Hepatosit Mencit (Mus Musculus L.) Setelah Paparan Ekstrak Air Biji Pepaya (Carica Papaya L.). Departemen Biologi, Fakultas Sains dan Matematika, Universitas Diponegoro, Semarang.

Whary, M. T., N. Baumgarth, J. G. Fox, and S. W. Barthold. 2015. Biology and Diseases of Mice Laboratory. Animan Medicine, 43149 